\title{
Phytoremediation of Mine Tailings Using Lolium Multiflorum
}

\author{
Violeta Mugica-Alvarez, Verónica Cortés-Jiménez, Mabel Vaca-Mier, and Victor Domínguez-Soria
}

\begin{abstract}
In this research we studied the feasibility of applying phytoremediation in the mine tailings at La Concha site. The extraction efficiency of heavy metals was studied, as well as the tolerance to high pollution and biomass generation of Lolium multiflorum, known as Italian ryegrass, in the aggressive soils composed almost entirely by mine wastes. Ryegrass seeds were grown in mine tailings containing $\mathrm{Cu}, \mathrm{Mn}$, $\mathrm{Zn}$, and $\mathrm{Pb}$ concentrations of around $800,4600,3200$, and 5400 ppm respectively. Triplicate analyses of soils without treatment and with treatments consisting in organic matter (OM) additions were carried out during 90 days. Italian ryegrass has a high tolerance to polluted mine tailings, although the addition of small quantities of organic matter improves the extraction of metals. The highest metals uptake from tailings was achieved through treatment with $20 \%$ OM additions, with varying efficiencies of around $50 \%$ for $\mathrm{Zn}$ and $\mathrm{Pb}$ in 90 days, although for $\mathrm{Cu}$ and $\mathrm{Mn}$ these were smaller, namely of 28 and $14 \%$ respectively. These results show that phytoremediation of mine tailings is possible through grass planting that was able to remove the heavy metals.
\end{abstract}

Index Terms-La Concha, México, phytoremediation, ryegrass, heavy metals.

\section{INTRODUCTION}

Environmental pollution caused by mining activities is a widespread problem throughout the world, which has negative consequences to human beings health, though largely to the environment. In México, the mining industry contributes with the $4.9 \%$ of the Gross Domestic Product [1]. Nevertheless this industry produces a considerably adverse environmental impact through each single production step: exploration, chemical and physical treatments affecting the soils during operations often have irreversible effects in soil properties, causing frequently its infertility, as well as inducing an important decrease in biodiversity [2], [3]. Furthermore, mining wastes contain high quantities of heavy metals that should be treated to avoid health risks to exposed populations.

Taxco mines in the State of Guerrero, México are among the most important producers of silver ever since colonial times, but in the XX century they also became important

Manuscript received April 28, 2014; revised July 17, 2014. This project was supported by the Universidad Autónoma Metropolitana, Azcapotzalco.

V. Mugica-Alvarez and V. Domínguez-Soria are with the Department of Basic Sciences, Universidad Autónoma Metropolitana-Azcapotzalco, México (e-mail: vma@correo.azc.uam.mx, vdds@correo.azc.uam.mx).

V. Cortés-Jiménez is with the Universidad Autónoma MetropolitanaAzcapotzalco (e-mail: lizvero@gmail.com).

M. Vaca-Mier is with the Department of Energy, Universidad Autónoma Metropolitana-Azcapotzalco, México (e-mail: mvm@correo.azc.uam.mx). zinc and lead producers, consequently, tons of tailings from the benefit of minerals over several decades have been dumped nearby the producing mines, such as the sites known as La Concha and El Fraile, where less than 10\% of the exposed surface has some kind of plant covering [4]. A brief visit to this site was enough to verify that at close quarters, to within than half a mile, there are dwellings and a secondary school. Next to and surrounding small agriculture lands and houses where their owners live, there are two large heaps of mine tailings: some of these inhabitants carry out their usual activities at distances less than 100 meters away from the said tailings. This means that people, animals and flora are highly exposed to high metal concentrations not only from wind and hydric dispersion, but also because the agricultural products grown at the sites could well contain metals; this situation represents a high risk to the population and the environment [5].

Phytoremediation is a biotechnological proposal that uses plants to stabilize, volatilize, extract or inactivate heavy metals and metalloids from polluted sites, reducing environmental risks; this is a cost-benefit technology, which is more attractive when compared to others that require intensive earth moving and expensive equipment [3], [6]. Phytoextraction is one of the mechanisms of phytoremediation that uptakes metals through the roots and to accumulate them subsequently in leaves and stems. Phytoremediation revegetates first polluted sites creating thus a plant covering that diminishes further dispersion of polluted dust through wind or water erosion [7], [8].

Phytoremediation is conducted taking advantage of native plants that tolerate the site's high pollution [9]. Nevertheless, it is necessary to make a study in the area to determine the feasibility of phytoremediation of such native plants, which should be grown off-site and then transplanted into the polluted ground and subsequently conserved [10]. Other alternative is the use of resistant species that can grow quickly, which apart from extracting metals can form a vegetal coverage to prevent soil erosion and dispersion.

This is the case of grasses capable of growing in many places with different adverse climate conditions, having massive and deep root systems, examples of which are the vetiver grass (Vetiveria zizanioides) [11], tropical grass (Brachiaria brizantha) [12], smilo grass (Piptatherum miliaceum) [13], Italian ryegrass (Lolium multiflorium) [14], (Zhang, 2005) and English ryegrass (Lolium perenne) [15]. Despite the studies mentioned the use of grasses has not been widely recognized or investigated in detail

Therefore, the aim of this paper is the application of phytoremediation at La Concha mine tailings using Italian ryegrass (Lolium multiflorum) in order to provide a green coverage that reduces the dispersion of polluted soil and 
exerts at the same time the gradual removal of heavy metals.

\section{MATERIALS AND METHODS}

\section{A. Study Site}

Mine tailings contaminated with metals were collected from the $0-20 \mathrm{~cm}$ surface layer of the tailings heap located at La Concha mine in the State of Guerrero, México $\left(18^{\circ} 32^{\prime} 23.32 \mathrm{~N}, 99^{\circ} 38^{\prime} 10.22 \mathrm{~W}\right)$. There are around 700 tons of mine wastes covering a surface area of 1.26 ha. The characterization of mine tailings and native plants has been reported previously [16].

Temperatures at the site range from 15 to $30^{\circ} \mathrm{C}$, the rains season is between June and September; the average precipitation is $246 \mathrm{~mm}$.

\section{B. Physicochemical Analysis of Tailings and Soils}

The unpolluted control soil that allowed observing the growth of seeds, was obtained from a clean garden in México. The soil and mine tailings were air-dried, crushed and mixed. Physicochemical analyses were carried out in the control and wastes. The $\mathrm{pH}$ was measured in a 1:2.5 tailings: water ratio slurry with a $\mathrm{pH}$ meter Orion Research; the cation exchange capacity (CEC) was measured using the ammonium acetate saturation method [17], the organic matter content (OM) was determined with the Walkley and Black method [18], the total nitrogen $\mathrm{N}$ with the Kjeldahl method. The available phosphorus [19] and sulphates were measured with the Islam and Bhuiyan procedure [20]. The analysis of metals $(\mathrm{Cu}, \mathrm{Ni}, \mathrm{Pb}$ and $\mathrm{Zn})$ was performed with induced coupled plasma (ICP-AES) Thermo Jarrel-Ash after acid digestion according to EPA method 3050 [21]

\section{Plant Samples Preparation and Metal Analysis of Grass}

The control soil and different combinations of mine tailings and organic matter were used to sow Italian ryegrass seeds (Lolium multiflorum). Besides the control soil, three treatments of soil and mine tailings were evaluated with triplicates each. The first treatment comprised only mine tailings, the second one was enriched with $20 \%$ organic matter (OM) added: the remnant was of mine tailings; the last one was $30 \% \mathrm{OM}$ and $70 \%$ of mine tailings. The organic matter added was a commercial organic soil improver inoculated with aerobic thermophilic bacteria, also with $85 \%$ organic matter, nitrogen, phosphorus and potassium. One gram of grass seeds were grown in the different soil treatments placed into plastic containers (15 $\mathrm{cm} \times 7 \mathrm{~cm}$, and $6 \mathrm{~cm}$ height). The containers were watered three times per week with $20 \mathrm{~mL} \mathrm{H}_{2} \mathrm{O}$. The DTPA-TEA$\mathrm{CaCl}_{2}$ method was applied to determine the bioavailability of the metals in the different treatments [22].

The metal contents in the three treatments and in the grasses were analyzed every 15 days up to 90 days total. Harvesting time was from March to June 2013 that is the driest season at the site. The grass shoots (above 6 to $15 \mathrm{~cm}$ from the node) were cut, washed with water and then with deionized water for further drying at $60{ }^{\circ} \mathrm{C}$ for three days. The materials were milled and acid-digested according to EPA 3015 method. Rhizospheric soil adhered to the roots of the grass was recovered and analyzed also to determine the metals content.

\section{Quality Control}

High purity standards were used for metal analyses (SRM 1515 standard reference material NIST). In addition reagent blanks and analytical duplicates were measured to ensure analytical accuracy and precision.

\section{E. Statistical Analysis}

The statistical analysis was carried out applying the program Statgraphics Centurion XVI.I. Differences among treatments and the control were determined with analysis of variance (ANOVA) followed by the Scheffe's test.

\section{RESUlTS AND DISCUSSION}

In general the ryegrass grew well in all treatments, with no visual signs of phytotoxicity observed in any of the samples, including those containing only mine tailings. Table I presents the physicochemical properties of the control soil and the three treatments before and after the experiments.

The $\mathrm{pH}$ values were neutral in the unmodified soil before planting grass and slightly alkaline with the addition of organic matter. After the experiments the $\mathrm{pH}$ was neutral in the first treatment as well as for the control, this means that the mobility of metals remains almost constant but it increased when organic matter $(\mathrm{OM} \%)$ was added before the experiments.

TABLE I: PhysicochemicAl Properties of TAILINGS AND PREPARED SOILS AT THE BEGINNING AND THE END OF EXPERIMENTS

\begin{tabular}{|c|c|c|c|c|c|c|c|c|}
\hline & \multicolumn{4}{|c|}{ Before experiments } & \multicolumn{4}{|c|}{ After experiments } \\
\hline & $\begin{array}{c}0 \% \text { added } \\
\text { OM }\end{array}$ & $\begin{array}{c}20 \% \text { added } \\
\text { OM }\end{array}$ & $\begin{array}{c}30 \% \text { added } \\
\text { OM }\end{array}$ & Control & $\begin{array}{c}0 \% \\
\text { added OM }\end{array}$ & $\begin{array}{c}20 \% \text { added } \\
\text { OM }\end{array}$ & $\begin{array}{c}30 \% \\
\text { added OM }\end{array}$ & Control \\
\hline pH & $7.14 \pm 0.2$ & $8.3 \pm 0.6$ & $8.4 \pm 0.1$ & $6.2 \pm 0.2$ & $7.24 \pm 0.1$ & $8.4 \pm 0.3$ & $8.1 \pm 0.2$ & $6.8 \pm 0.2$ \\
\hline ОМ\% & $0.44 \pm 0.2$ & $1.32 \pm 0.6$ & $1.9 \pm 0.5$ & $7.37 \pm 2.1$ & $0.34 \pm 0.2$ & $1.4 \pm 0.8$ & $5.3 \pm 1.5$ & $7.41 \pm 1.5$ \\
\hline CEC cmolkg-1 & $1.1 \pm 0.2$ & $1.8 \pm 1.4$ & $4.6 \pm 1.2$ & $16.3 \pm 1.8$ & $3.2 \pm 1.2$ & $9.7 \pm 2.3$ & $7.4 \pm 1.6$ & $14.4 \pm 1.8$ \\
\hline Sulphate mmolL ${ }^{-1}$ & $3.5 \pm 0.5$ & $8.3 \pm 4.2$ & $8.8 \pm 3.5$ & $4.8 \pm 1.5$ & $2.2 \pm 0.2$ & $10.7 \pm 0.6$ & $10.1 \pm 1.7$ & $1.5 \pm 1.1$ \\
\hline Av. $P$ mgkg $^{-1}$ & $1.01 \pm 0.6$ & $10.8 \pm 2.8$ & $15.8 \pm 3.1$ & $33.1 \pm 4.3$ & $1.86 \pm 0.5$ & $18.1 \pm 1.6$ & $19.8 \pm 3.3$ & $39.9 \pm 2.5$ \\
\hline Total N\% & $0.02 \pm 0.01$ & $0.02 \pm 0.01$ & $0.01 \pm 0.01$ & $0.33 \pm 0.1$ & $0.2 \pm * 0.1$ & $0.01 \pm 0.01$ & $0.03 \pm 0.01$ & $0.43 \pm 0.1$ \\
\hline
\end{tabular}


The organic matter contents in the tailings were less than $1 \%$, although after harvesting the OM \% increased slightly, mainly in the case of the third treatment with $30 \%$ of OM added.

Cation exchange capacity (CEC) values were lower at the beginning and increased after the 90 day indicating the modification of the physicochemical properties due to the grass. The $\mathrm{P}$ content was high before experiments and increased slightly after the experiments. Regarding the $\mathrm{P}$ total content, it increased with the increase of organic matter, and after the experiments, showing an improvement of the content of this nutrient to the plants.

The $\mathrm{N}$ concentration was very low before the experiments and was almost not modified after the experiments, with the exception of the control soil.

Table II gives the content of total metal and DTPAextractable metal in the different treatments. Total concentrations of the four metals are high; $\mathrm{Zn}$ concentrations were nine-fold higher than the limit proposed by WHO in soils, corresponding to $\mathrm{mgKg}^{-1} ; \mathrm{Pb}$ concentrations were almost seven-fold higher that the standard for industrial soils $\left(800 \mathrm{mgKg}^{-1}\right)$. Further, it is observed that the DTPA-extractable $\mathrm{Cu}$ in the three treatments is around 2\%, whereas the available DTPA extractable $\mathrm{Mn}$ is 0.01 when OM was not added and between $0.3 \%$ and $0.4 \%$ after adding $\mathrm{OM}$, the $\mathrm{Zn}$ extracted by DTPA was $43 \%$ when OM was not added, and $65 \%$ when OM was incorporated, finally the DTPA-extractable $\mathrm{Pb}$ was $5.6 \%, 12.8 \%, 13.3 \%$ when $0 \%, 20 \%$ and $30 \%$ of OM was added.

With the exception of $\mathrm{Cu}$ that presented almost the same DTPA extracted concentration in the three treatments, the other metals increased the extraction by DTPA when the OM was added to the original mine tailings. The Scheffe test showed for all the metals significant differences in DTPA when $\mathrm{OM}$ was added, although for $\mathrm{Mn}, \mathrm{Zn}$ and $\mathrm{Pb}$ there is no significant difference whether $20 \%$ or $30 \%$ were added (significant differences are shown with different letter superindexes).

TABLE II: TOTAL AND DTPA-EXTRACTABLE METAL $\left(\mathrm{mgKg}^{-1}\right)$

\begin{tabular}{|lccc|}
\hline $\begin{array}{r}\text { OM\% } \\
\text { content }\end{array}$ & $\mathbf{0 \%}$ & $\mathbf{2 0 \%}$ & $\mathbf{3 0 \%}$ \\
\hline Total Cu & $799 \pm 36^{\mathrm{A}}$ & $668 \pm 29^{\mathrm{A}}$ & $562 \pm 27^{\mathrm{A}}$ \\
\hline Total Mn & $4631 \pm 59^{\mathrm{A}}$ & $3925 \pm 93^{\mathrm{AB}}$ & $3325 \pm 21.16^{\mathrm{B}}$ \\
\hline Total Zn & $3231 \pm 128^{\mathrm{A}}$ & $2597 \pm 138^{\mathrm{AB}}$ & $2188 \pm 122^{\mathrm{B}}$ \\
\hline Total Pb & $5408 \pm 76^{\mathrm{A}}$ & $4463 \pm 91^{\mathrm{AB}}$ & $3594 \pm 147^{\mathrm{B}}$ \\
\hline & & & \\
\hline DTPA- Cu & $15.7^{\mathrm{C}} \pm 1.0$ & $12.6^{\mathrm{B}} \pm 0.6$ & $10.6^{\mathrm{A}} \pm 0.4$ \\
\hline DTPA- Mn & $0.6^{\mathrm{A}} \pm 0.2$ & $13.5^{\mathrm{C}} \pm 4.2$ & $14.7^{\mathrm{C}} \pm 1.3$ \\
\hline DTPA- Zn & $1391^{\mathrm{A}} \pm 43.7$ & $1700^{\mathrm{B}} \pm 84.1$ & $1430^{\mathrm{AB}} \pm 167$ \\
\hline DTPA- Pb & $295^{\mathrm{A}} \pm 53.8$ & $571^{\mathrm{C}} \pm 50.1$ & $479^{\mathrm{C}} \pm 36.3$ \\
\hline
\end{tabular}

Fig. 1 shows the comparison of biomass generation in the control soil and the three treatments, where it is observed that the lowest biomass was attained with Treatment 1 when organic matter was not incorporated to the mine tailings. This is because the amount of nutrients is low in addition to the high metal content.
Despite the high metals content in treatment 2 and 3, these presented quite a similar biomass generation respect to that presented by the control soil, with insignificant differences among these treatments, suggesting that the high metal content is not the main reason for the low plant growth but that this is due to the lack of nutrients.

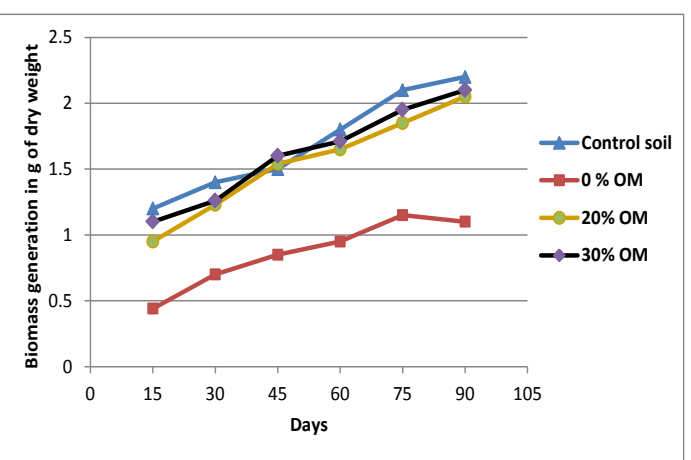

Fig. 1. Biomass generated in the control soil and different treatments.

The greatest reductions achieved due to phytoremediation with Italian ryegrass are presented in Table III, where it is possible to see that with the exception of $\mathrm{Zn}$, the other three metals had the best reductions after the 20\% OM addition treatment, followed by the mine tailings without OM. In all cases the lowest reduction was attained by the treatment with $30 \%$ of OM. This behavior suggests that although the addition of $\mathrm{OM}$ can improve the removal of metals, the excess of $\mathrm{OM}$ can absorb them decreasing their availability for grass extraction. The behavior for each metal is discussed in the next section.

TABLE III: BEST METAL REDUCTIONS ACHIEVED

\begin{tabular}{|lccc|}
\hline & Treatment & $\mathbf{m g K g}^{-1}$ reduced & Reduction \% \\
\hline $\mathbf{C u}$ & $20 \% \mathrm{OM}$ & 185 & 27.7 \\
\hline $\mathbf{M n}$ & $20 \% \mathrm{OM}$ & 554 & 14.1 \\
\hline $\mathbf{P b}$ & $20 \% \mathrm{OM}$ & 1373 & 50.8 \\
\hline $\mathbf{Z n}$ & $0 \% \mathrm{OM}$ & 2776 & 51.3 \\
\hline
\end{tabular}

Fig. 2 presents the behavior of different soils after treatments for the reduction of metals by planting ryegrass. Throughout the 90 weeks, the $\mathrm{Cu}$ concentration in the different treatments of mine tailings decreased up to $28 \%$ after adding $20 \%$ of OM, which presents a statistically significant difference with the other two treatments, followed by the mine tailings without $\mathrm{OM}$, that gave a $\mathrm{Cu}$ reduction of $16 \%$ and finally the treatment with $30 \%$ of OM that allowed achieving a $\mathrm{Cu}$ reduction of $9 \%$.

Mn reduction with the different treatments had the lowest reductions as compared with the other metals, probably due to the low DTPA bioavailability of this metal $(0.01$ to $0.4 \%$ ). Reductions of $14.1 \%, 11.9 \%$, and $9.1 \%$ were achieved with the treatments containing $20 \%$ of OM, $0 \%$ of $\mathrm{OM}$ and $30 \%$ of OM, respectively. This last treatment presented significant difference with the other treatments.

$\mathrm{Pb}$ uptake patterns of the ryegrass indicate once more that the highest reduction percentage $(51 \%)$ was with the $20 \%$ OM treatment, although the highest reduction in mass was $1576 \mathrm{mgPbKg}^{-1}$ corresponding to $49 \%$ reduction with the treatment without $\mathrm{OM}$. The $\mathrm{Pb}$ reduction decreased significantly (18\%) after treatment with $30 \%$ of OM, 
thereby presenting a significant difference with the other treatments, showing once again that the excess $\mathrm{OM}$ induces an interaction with the metals decreasing their availability for phytoextraction.

Finally, the greater $\mathrm{Zn}$ reduction by the grass $(51.33 \%)$ was obtained without the addition of OM, followed by the $20 \% \mathrm{OM}$ and $30 \% \mathrm{OM}$ additions that gave reductions of $43.3 \%$ and $18.5 \%$ respectively. These results confirm on the one hand that the phytotoxicity due to high pollution of metals is low for the Italian ryegrass, and on the other that the high DTPA bioavailability of $\mathrm{Zn}(26-40 \%)$ is a very important factor for the phytoextraction of metals.

The assessment of plants efficiency for phytoextraction was carried out with the bioconcentration factor (BCF) which is defined as the ratio of metal biomass concentration to metal concentration in the soil [23], (1).

$$
\mathrm{BCF}=\mathrm{C}_{\text {shoots }} / \mathrm{C}_{\text {soil }} \text {, }
$$

where $\mathrm{C}$ represents the metal concentration.

Table IV displays the estimated values of $\mathrm{BCF}$ for the different treatments with planting ryegrass at different times. The exception in all cases is when $30 \%$ of OM was added, which suggests that with this concentration the OM adsorbs the metals, thus subtracting them out from the ryegrassexerted decrease. The $\mathrm{BCF}$ values increase gradually with time: the highest are around 1 for $\mathrm{Pb}$ and $\mathrm{Zn}$, which explain the removal percentages of each metal presented in Table III Conversely, the $\mathrm{BCF}$ for $\mathrm{Cu}$ and $\mathrm{Mn}$ are lower than 0.5. These results suggest that the Italian ryegrass is not a hyperaccumulating plant. However, there are very few hyperaccumulating plants with the capacity for multiple metal bioaccumulation, and they do not grow anywhere; then it is important to consider other types of plants capable of extracting metals without their not being hyperaccumulating. The results in this study show that Lolium Multiflorum, has the ability to extract metals, has tolerance to the presence of high metal concentrations, and grows easily and fast in soils with low nutrient conditions. Besides, the ryegrass forms a vegetal coverage that prevents erosion and dispersion of the mine tailings.

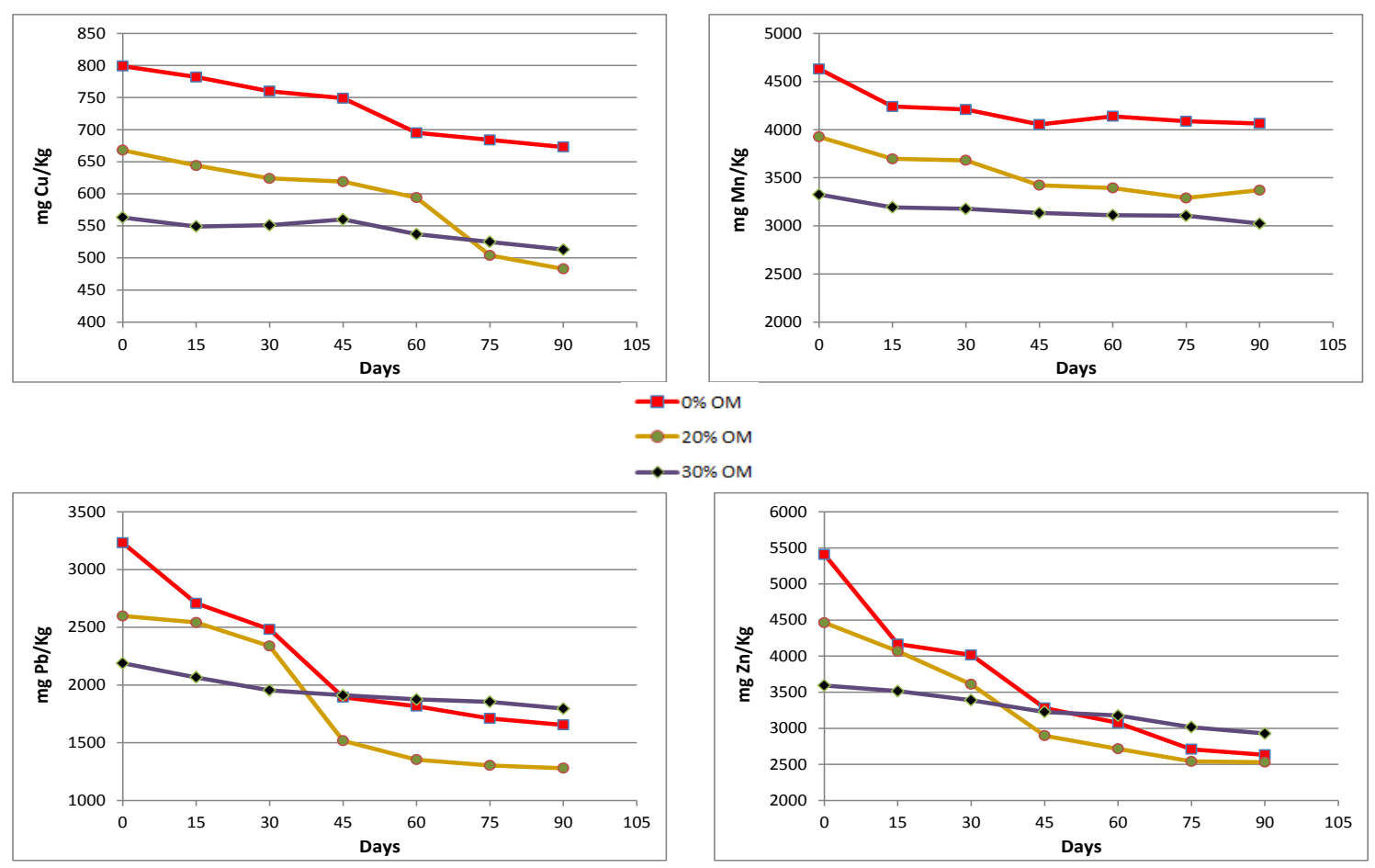

Fig. 2. Reduction of $\mathrm{Cu}, \mathrm{Mn}, \mathrm{Pb}$, and $\mathrm{Zn}$ obtained after the different soil treatments.

\begin{tabular}{|c|c|c|c|c|c|c|c|c|c|c|c|c|}
\hline \multirow[t]{3}{*}{ Days } & \multicolumn{3}{|c|}{$\mathrm{Cu}$} & \multicolumn{3}{|c|}{$\mathrm{Mn}$} & \multicolumn{3}{|c|}{$\mathrm{Pb}$} & \multicolumn{3}{|c|}{$\mathrm{Zn}$} \\
\hline & 0\% & $20 \%$ & $30 \%$ & $0 \%$ & $20 \%$ & $30 \%$ & 0\% & $20 \%$ & $30 \%$ & 0\% & $20 \%$ & $30 \%$ \\
\hline & OM & OM & OM & OM & OM & OM & OM & OM & OM & OM & OM & OM \\
\hline 15 & 0.06 & 0.06 & 0.05 & 0.06 & 0.04 & 0.03 & 0.19 & 0.07 & 0.04 & 0.27 & 0.09 & 0.14 \\
\hline 30 & 0.07 & 0.07 & 0.05 & 0.07 & 0.04 & 0.04 & 0.29 & 0.12 & 0.06 & 0.34 & 0.34 & 0.12 \\
\hline 45 & 0.11 & 0.15 & 0.06 & 0.10 & 0.12 & 0.05 & 0.70 & 0.73 & 0.07 & 0.60 & 0.53 & 0.14 \\
\hline 60 & 0.12 & 0.22 & 0.07 & 0.12 & 0.14 & 0.08 & 0.78 & 0.91 & 0.10 & 0.72 & 0.61 & 0.16 \\
\hline 75 & 0.14 & 0.29 & 0.08 & 0.13 & 0.14 & 0.09 & 0.90 & 1.03 & 0.13 & 0.95 & 0.81 & 0.22 \\
\hline 90 & 0.16 & $\mathbf{0 . 3 4}$ & 0.09 & 0.13 & 0.15 & 0.10 & 0.92 & 1.14 & 0.17 & 1.02 & 0.94 & 0.24 \\
\hline
\end{tabular}

\section{CONCLUSIONS}

Although Italian ryegrass (Lolium multiflorum) is not a hyperaccumulating plant, it is able to grow in mine tailing soils, and uptake heavy metals such as $\mathrm{Pb}$ and $\mathrm{Zn}$ with a good efficiency. When the soil is enriched with $20 \%$ of organic matter their metal extraction properties are improved, however if the enrichment with organic matter is exceeded the metals became less available for plant 
extraction.

Italian ryegrass is suitable for phytoestabilization since it does not require high watering quantities and grows fast in aggressive soils, forming a green cover that limits the dispersion of polluted dust and can uptake gradually the heavy metals improving the soil properties.

\section{ACKNOWLEDGMENTS}

Authors thanks to the Universidad Autónoma Metropolitana Azcapotzalco by the financial support of this project, as well as to Silvia Martínez by her support in the soil analysis.

\section{REFERENCES}

[1] Economy Secretariat 2013. Statistics of Mining Sector. [Online] Available: http://www.economia.gob.mx/comunidadnegocios/mineria/estadisticas-y-estudios-del-sector

[2] M. H. Wong, "Ecological restoration of mine degraded soils, with emphasis on metal contaminated soils," Chemosphere, vol. 50, pp. $775-780,2003$

[3] K. P. Prabha and L. Y. Li, "Phytoremediation technology: Hyperaccumulation metals in plants," Water and Air Soil Pollution, vol. 184 no. 1 , pp. 105-126, 2007

[4] O. T. Mendoza, M. Yta, R. M. Tovar, A. D. Almazán, N. F. Mundo, and C. D. Gutiérrez, "Mineralogy and geochemistry of sulfide-bearing tailings from silver mines in Taxco, México area to evaluate their potential environmental impact," Geofisica Internacional, vol. 44, pp. 49-64, 2005.

[5] D. Mains, D. Craw, and C. G. Rufaut, "Phytostabilization of gold mine tailings, New Zealand. Part 1: Plant establishment in alkaline saline substrate," International Journal of Phytoremediation, vol. 8 , pp. 131-147, 2006.

[6] G. Sarret, J. Vangronsveld, A. Manceau, M. Musso, J. D’Haen, J. J. Mentones, and J. L. Hazemann, "Accumulation forms of $\mathrm{Zn}$ and $\mathrm{Pb}$ in Phaseolus vulgaris in the presence and absence of EDTA," Environmental Science \& Technology, vol. 35, no. 13, pp. 2854-2859, 2001.

[7] U. Kukier and R. L. Chaney, "In situ remediation of nickel phytotoxicity for different plant species," Journal of Plant Nutrition, vol. 27, pp. 465-495, 2004.

[8] J. Yoon, X. Cao, Q. Zhou, and L. Q. Ma, "Accumulation of $\mathrm{Pb}, \mathrm{Cu}$, and $\mathrm{Zn}$ in native plants growing on contaminate Florida site," Science of the Total Environmental, vol. 368, pp. 456-464, 2006.

[9] O. Barrutia, U. Artetxw, A. Hernandez, J. M. Olano, J. I. GarcíaPlazaola, C. Garbisu, and J. M. Becerril, "Native plant communities in an Abandoned $\mathrm{Pb}-\mathrm{Zn}$ mining área of northern spain: Implications for phytoremediation and germplasm preservation," International Journal of Phytoremediation, vol. 13, pp. 256-270, 2011.

[10] Y. G. Liu, H. Z. Zhang, G. M. Zeng, B. R. Huang, and X. Li, "Heavy metal accumulation in plants on Mn mine tailings," Pedosphere, vol. 16, pp. 131-136, 2006.

[11] Y. Chen, Z. Shen, and X. Li, "The use of vetiver grass, Vetiveria zizanioides in the phytoremediation of soils contaminated with heavy metals," Applied Geochemistry, vol. 19, no. 10, pp. 1553-1565, 2004.

[12] N. Merkl, R. Schultze-Kraft, and C. Infante, "Assessment of tropical grasses and legumes for phytoremediation of petroleum-contaminated soils," Water, Air, and Soil Pollution, vol. 165, no. 1-4, pp. 195-209, 2005.

[13] G. Garcia, A. Faz, and M. Cunha, "Performance of Piptatherum miliaceum, (Smilo grass) in edaphic $\mathrm{Pb}$ and $\mathrm{Zn}$ phytoremediation over a short growth period, International Biodeterioration \& Biodegradation, vol. 54, no. 2, pp. 245-250, 2004.

[14] L. Zhang, H. X. Li, W. F. Ma, and X. H. Zhao, "Phytoremediation of complex contaminations in dredged sewage river sediment by Lolium multiflorum Lam," Journal of Agro-Environment Science, vol. 25, no. 1, pp. 107-112, 2006.

[15] D. L. Johnson, D. R. Anderson, and S. P. McGrath, "Soil microbial response during the phytoremediation of a PAH contaminated soil," Soil Biology and Biochemistry, vol. 37, no. 12, pp. 2334-2336, 2005.

[16] E. V. Cortés-Jiménez, V. Mugica-Álvarez, M. C. A. GonzálezChávez, R. Carrillo-González, M. Martínez Gordillo, and M. Vaca Mier, "Natural revegetation of alkaline tailing heaps at Taxco, Guerrero, México," International Journal of Phytoremediation, vol. 15, no. 2, pp. 127-141, 2012.
[17] D. J. Rowell, Soil Science: Methods and Applications, 2nd ed. Longman, Essex, England, 1996.

[18] D. W. Nelson and L. E. Sommers, "Total carbon, organic matter," in Methods of Soil Analysis, Part 2, Agronomy 9, A. L. Page et al., Eds. American Society of Agronomy, Madison, 1982, pp. 539-279.

[19] S. R. Olsen and L. A. Dean, "Phosphurus," in Methods of Soil Analysis, Part 2, Agronomy 9, C. A. Black Ed. American Society of Agronomy, Madison, Wisconsin, 1965, pp. 1035-1049.

[20] M. Islam and N. Bhuiyan, "Evaluation of various extractants for available sulfur in wetland rice (Oryza sativa) soils of Bangladesh," Indian Journal of Agriculture Science, vol. 58, pp. 603-606, 1998

[21] EPA (Environmental Protection Agency) Acid Digestion of Sediments, Sludge, and Soils, Método 3050A, 1992.

[22] W. L. Lindsay and W. A. Norvell, "Development of a DTPA soil zinc, iron, manganese and copper," Soil Science Society of America Journal, vol. 42, pp. 421-428, 1978.

[23] S. P. McGrath and F. J. Zhao, 'Phytoextraction of metals and metalloids from contaminatedsoils," Curr. Opin. Biotechnol, vol. 14 pp. 277-282, 2003

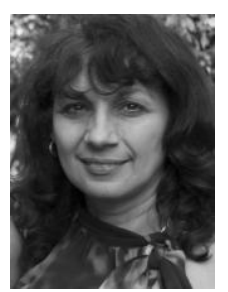

Violeta Mugica-Alvarez was born in México City She is a chemist for the Universidad Nacional Autónoma de México (UNAM). She got the master and the Ph.D. degrees in environmental engineering from UNAM.

She is a full time professor at the Universidad Autónoma Metropolitana and is the co-ordinator of the masters in environmental science and engineering.

Dr. Mugica has carried out research related to air and soil pollution, and related to the control and prevention of environmental pollution and emission of greenhouse gases. She is the author of more than 40 papers published in international journals, several book chapters in the field of environmental sciences, mainly in air and soil pollution. She has participated in more than one hundred national and international conferences.

Dr. Mugica has been a consultant of the environment secretariat and of the United Nations Development Program for the assessment of Actions to prevent air pollution in México City and for the assessment of adaptation actions to face Climatic Change. She is a member of the National System of Researchers (SNI) at level two, which is a national distinction awarded to Mexican researchers.

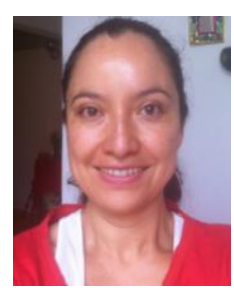

Veronica Cortés-Jiménez was born in México City, on September 20, 1975. She has a bachelor degree in civil engineering of the National Autonomous University of México, UNAM in 2000 and a master degree in environmental engineering and science of the Autonomous Metropolitan UniversityAzcapotzalco, UAM-A in 2008. She is finishing her $\mathrm{Ph} . \mathrm{D}$. studies in environmental science and engineering at UAM-A. Her major field of study is exploring the capacities of various plants in the extraction of heavy metals, mainly $\mathrm{Cu}, \mathrm{Pb}, \mathrm{Zn}$ and $\mathrm{Mn}$, from heavily polluted soil.

She participated in various seminars on: phytoremediation in mine waste, toxicity of heavy metals in human beings and the implication of mine activity in polluted soils such as "Phytoextraction of $\mathrm{Ni}$, $\mathrm{As}$ and $\mathrm{Cu}$ in polluted soil of urban/industrial Sites" in the "Second International Workshop of biotechnology and the second international meeting on alternative energies" held in in Pachuca, Hgo. She worked as a civil engineer in the private companies "Hamon Corporation" in Monterey, México and in "COREY" in México City, as well as within the Government of México City in the "Dirección General de Servicios Urbanos" from 2003-2006.

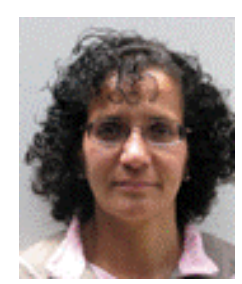

Mabel Vaca Mier was born in México City. She has a master degree in engineering from McGill University, Canada in 1985. She has a Ph.D. in environmental engineering, UNAM, México in 1999

She is a full professor at the Energy Department of the Autonomous Metropolitan University, UAM, Azcapotzalco campus, in México City. Her current research interests are focused on soil remediation technologies, industrial wastes management and wastewater treatment and disinfection and reuse of treated waters. She has published more than 30 papers in international journals. She is a member of the National System of Researchers (SNI) at level two, which is a distinction awarded to Mexican researchers. 


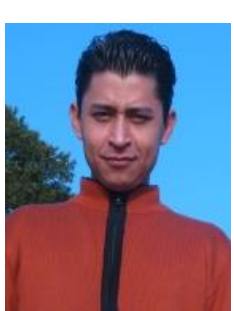

Victor Domínguez Soria was born in México City in 1979. He completed his undergraduate studies in chemical engineering at the Azcapotzalco campus of the Metropolitan Autonomous University (UAM-A) in México in 2003. He received his Ph.D. degree in chemical sciences from the Chemistry Department of CINVESTAV (México-DF) in 2009.

He was a fellow researcher at CINVESTAV on the software development for nanomaterials simulation project from 2009-2011. During 2012 he was a visiting researcher in the Basic Sciences and Engineering Department of UAM-A. Since 2013, he is a researcher-professor in the applied chemistry Area at UAM-A. His research is focused on the development and application of computational methodologies for environmental and materials studies. Dr. Domínguez is a member of the deMon developers community and the Mexican Academy of Catalysis (ACAT). He is a member of the National System of Researchers (SNI) at level one. 